\title{
Marigold Growth and Phosphorus Leaching in a Soilless Medium Amended with Phosphorus-charged Alumina
}

\author{
Yuan-ling P. Lin ${ }^{1}$, E. Jay Holcomb ${ }^{2}$, and Jonathan P. Lynch ${ }^{3}$ \\ Department of Horticulture, The Pennsylvania State University, University \\ Park, PA 16802
}

Additional index words. Tagetes erecta, Tagetes petula, Tagetes erecta $\mathrm{x}$ Tagetes petula

\begin{abstract}
Alumina granules charged with $P$ were used as an amendment to improve the ability of a soilless medium to retain $P$ and provide it to plants. Commercially available alumina was acidified, saturated with $P$, and evenly distributed in a medium of peat, vermiculite, and sand to grow potted marigolds (Tagetes spp.) to a commercially salable stage. Marigolds grown in medium amended with P-charged alumina had adequate nutrition and similar or superior shoot growth (as measured by height, number of branches, and flower production) and fresh and dry weights compared to marigolds grown using commercial fertilizer. Phosphorus-charged alumina at $1 \%$ or $2 \%$ of total medium volume was sufficient to grow marigolds for at least 8 weeks and substantially reduced $P$ leaching compared to conventionally fertilized controls. Alumina amendments in this range did not cause Al toxicity, as evidenced in root growth and leaf Al content.
\end{abstract}

Soilless media are popularly used in greenhouse crop production (Peters, 1992) because they are relatively lightweight, free from diseases, readily available, and more uniform and more suitable for containerization than mineral soils (Bunt, 1988; Flegmann and George, 1977; Nelson, 1991). Peat, vermiculite, perlite, bark, and rockwool are used the most extensively. These components, however, have poor P-retaining ability (Fox and Kamparath, 1971; Marconi and Nelson, 1984) and they allow as much as $75 \%$ of the P applied to be leached and lost (Yeager and Barrett, 1984). Thus, they result in inefficient fertilizer use and environmental contamination.

Efforts to alleviate $\mathrm{P}$ leaching in soilless media have included incubation with superphosphate (Yeager and Barrett, 1985) and amendment with anion exchange resins (Yeager and Barrett, 1986). These treatments were time-consuming, expensive, and failed to reduce $P$ leaching. In addition, the effects of these materials on plants were not studied. As an alternative method for reducing $P$ leaching from soilless media while producing favorable plant response, we evaluated a solidphase $\mathrm{P}$-charged alumina $\left(\mathrm{P}-\mathrm{Al}_{2} \mathrm{O}_{3}\right)$ as an amendment for soilless media. Phosphoruscharged alumina was first developed as an amendment in experimental sand culture systems for P nutritional studies (Coltman et al., 1982). Combining $\mathrm{P}-\mathrm{Al}_{2} \mathrm{O}_{3}$ with sand successfully supplied $\mathrm{P}$ and maintained constant and steady $\mathrm{P}$ concentrations for plant growth

Received for publication 17 Apr. 1995. Accepted for publication 9 Oct. 1995. The cost of publishing this paper was defrayed in part by the payment of page charges. Under postal regulations, this paper therefore must be hereby marked advertisement solely to indicate this fact.

${ }^{1}$ Graduate Student of Horticulture.

${ }^{2}$ Professor of Floriculture.

${ }^{3}$ Assistant Professor of Plant Nutrition.
(Coltman et al., 1982; Elliott, 1989; Elliott et al., 1983; Lynch et al., 1990). Our objective was to examine the utility of P-charged alumina as a P source for plant growth that would minimize $\mathrm{P}$ leaching from a soilless medium.

\section{Materials and Methods}

$\mathrm{P}-\mathrm{Al}_{2} \mathrm{O}_{3}$. Dry alumina (1.2 kg Alcoa, Grade F1, 28 to 48 mesh, $92.1 \% \mathrm{Al}_{2} \mathrm{O}_{3}, 7.2 \% \mathrm{SiO}_{2}$ ) was loaded into a polyvinyl chloride (PVC) column with an inlet and outlet to a 100-liter tank. Alumina $\left(\mathrm{Al}_{2} \mathrm{O}_{3}\right)$ was first rinsed with distilled water until the rinsate was colorless, then it was treated with $0.05 \mathrm{~N} \mathrm{HCl}$ for $24 \mathrm{~h}$ by continuously recirculating the acid through the column. Acid-treated $\mathrm{Al}_{2} \mathrm{O}_{3}$ was rinsed by circulating distilled water through the column for $3 \mathrm{~h}$. Columns were rinsed three times. The final $\mathrm{pH}$ of the $\mathrm{Al}_{2} \mathrm{O}_{3}$ was adjusted to obtain an equilibrium $\mathrm{pH}$ of 5.5 by adding $0.5 \mathrm{~N} \mathrm{KOH}$ or $\mathrm{HCl}$ (Lynch et al., 1990). A solution of $10 \mathrm{~mm}$ $\mathrm{KH}_{2} \mathrm{PO}_{4}$ (100 liters) was circulated through the $\mathrm{pH}$-adjusted $\mathrm{Al}_{2} \mathrm{O}_{3}$ for $72 \mathrm{~h}$. The $\mathrm{P}$-charged $\mathrm{Al}_{2} \mathrm{O}_{3}$ then was removed from the PVC column and oven-dried at $49 \pm 1 \mathrm{C}$ for 2 days before use.

Growing media. The germination medium consisted of a 1 peat (Hyde Park, Canadian sphagnum; Conrad Fafard, Agawan, Mass.) : 1 vermiculite (Terra-Lite, grade 3; W.R. Grace \& Co. Horticultural Products, Cambridge, Mass.) (v/v) ratio. The potting medium was a mix of 2 peat : 2 vermiculite : 1 sand (Play sand; Louisiana-Pacific, Portland, Ore.) (by volume). For the potting medium amended with $\mathrm{P}-\mathrm{Al}_{2} \mathrm{O}_{3}, \mathrm{P}-\mathrm{Al}_{2} \mathrm{O}_{3}$ was substituted for an equal volume of sand.

Fertilizer and nutrient solutions. One treatment was $20 \mathrm{~N}-4.4 \mathrm{P}-16.6 \mathrm{~K}$ fertilizer (PeatLite Special; Scotts Co., Marysville, Ohio) dissolved in water to produce a solution containing $7100 \mu \mathrm{M} \mathrm{N}$. The complete nutrient solution (CNS) treatment contained (in $\mu \mathrm{M})$
$1500 \mathrm{KNO}_{3}, 1200 \mathrm{Ca}\left(\mathrm{NO}_{3}\right)_{2}, 400 \mathrm{NH}_{4} \mathrm{NO}_{3}, 25$ $\mathrm{MgCl}_{2}, 5$ FeEDTA, $500 \mathrm{MgSO}_{4}, 300 \mathrm{~K}_{2} \mathrm{SO}_{4}$, $300\left(\mathrm{NH}_{4}\right)_{2} \mathrm{SO}_{4}, 1.5 \mathrm{MnSO}_{4}, 1.5 \mathrm{ZnSO}_{4}, 0.5$ $\mathrm{CuSO}_{4}, 0.143\left(\mathrm{NH}_{4}\right)_{6} \mathrm{Mo}_{7} \mathrm{O}_{24}, 0.5 \mathrm{Na}_{2} \mathrm{~B}_{4} \mathrm{O}_{7}$, and $400 \mathrm{KH}_{2} \mathrm{PO}_{4}$ (Lynch et al., 1990) (Table 1). The nutrient solution used for the aluminaamended pots did not contain $\mathrm{KH}_{2} \mathrm{PO}_{4}$. In the second experiment, the concentration of $\mathrm{Cu}$ was doubled from 0.5 to $1 \mu \mathrm{M}$.

Growth responses of marigold genotypes over a narrow range of alumina treatments (Expt. 1)

Treatments. Five treatments were used, including a commercial control (potting medium fertilized with $20 \mathrm{~N}-4.4 \mathrm{P}-16.6 \mathrm{~K}$ ), potting medium fertilized with CNS, and potting medium amended with alumina at $2 \%, 4 \%$, or $8 \%$ of medium volume and fertilized with the minus $\mathrm{P}$ nutrient solution.

Experiment design. A randomized complete-block design was used with a total of eight blocks for two harvest times. Each harvest consisted of four blocks. The first four blocks were randomly chosen and harvested after 4 weeks and the remaining four after 8 weeks. Each block contained 20 plants, one each from the five treatments and four cultivars of marigolds. Results were analyzed by analysis of variance (SAS, 1989).

Plant culture. Marigold seeds (G.S. Grimes Seeds, Concord, Ohio) of four cultivars, 'Discovery' (Tagetes erecta L.), 'Inca' (T. erecta L.), 'Sophia' (T. patula L.), and 'Nugget Supreme' (T. erecta L. XT. patula L.), were sown in trays containing moist germination medium [1 peat : 1 vermiculite (v/v)] on 12 July 1993. Once sown, trays were soaked in distilled water until the medium was wet. Trays then were covered with clear plastic bags and placed in darkness in a growth room at $22 \pm 2 \mathrm{C}$ for 3 days. After germination, the plastic bags were removed and the trays were exposed to fluorescent light with an irradiance level of $75 \pm 5$ $\mu \mathrm{mol} \cdot \mathrm{m}^{-2} \cdot \mathrm{s}^{-1}$ photosynthetically active radiation (PAR) for $24 \mathrm{~h} \cdot \mathrm{day}^{-1}$. One week after seeds were sown, seedlings were transplanted into inserts (Type $806,53 \times 28 \mathrm{~cm}$; E.C. Geiger, Harleysville, $\mathrm{Pa}$.) that contained moist germination medium soaked with distilled water and placed on a greenhouse bench. The greenhouse was heated to $\approx 18.5 \mathrm{C}$ and ventilated at $24 \mathrm{C}$. After 1 week in inserts, 40 uniform seedlings per cultivar were chosen and

Table 1. Nutrient composition in the $20 \mathrm{~N}-4.4 \mathrm{P}-$ $16.6 \mathrm{~K}$ (control) fertilizer, complete nutrient solution (CNS), and minus P solution (MPS).

\begin{tabular}{lccc}
\hline & \multicolumn{3}{c}{ Nutrient composition $\left(\mathrm{mg}^{\circ}\right.$ liter $\left.^{-1}\right)$} \\
\cline { 2 - 4 } Element & Control & CNS & MPS \\
\hline $\mathrm{N}$ & 100 & 74 & 74 \\
$\mathrm{P}$ & 22 & 12.4 & --- \\
$\mathrm{K}$ & 83 & 99 & 82 \\
$\mathrm{Ca}$ & --- & 48 & 48 \\
$\mathrm{Mg}$ & 0.75 & 12.76 & 12.76 \\
$\mathrm{Mn}$ & 0.28 & 0.08 & 0.08 \\
$\mathrm{Fe}$ & 0.50 & 0.28 & 0.28 \\
$\mathrm{Cu}$ & 0.05 & 0.03 & 0.03 \\
$\mathrm{~B}$ & 0.10 & 0.005 & 0.005 \\
$\mathrm{Mo}$ & 0.05 & 0.01 & 0.01 \\
\hline
\end{tabular}


transplanted one to each 550-ml $(10-\mathrm{cm})$ square pot and grown in the same greenhouse. Trickle irrigation was used and fertilizer or nutrient solutions were applied with each irrigation.

Data collection. Flowering date was recorded when the petals of the first flower showed coloration. Buds longer than $1 \mathrm{~cm}$ were counted. Branches were counted when they were $>2 \mathrm{~cm}$ long. At harvest, shoots were cut off at the soil line, weighed, dipped in diluted P-free detergent (Liqui-Nox; Alconox, New York), and rinsed with distilled water a few times to wash off surface contamination. Washed plants were dried 3 days at $49 \pm 1 \mathrm{C}$ then weighed. A sample of the surplus irrigation water (leachate) from each irrigation was collected each week. Phosphorus content of ashed plant tissue and leachate was determined colorimetrically (Murphy and Riley, 1962).

\section{Growth responses of 'Nugget Supreme' marigold to a wide range of alumina treatments, and total $\mathbf{P}$ leached (Expt. 2 )}

Treatments. Eight treatments were used, including a commercial control, CNS, and alumina at $1 \%, 2 \%, 4 \%, 8 \%, 12 \%$, and $16 \%$ by volume.

Experiment design. A randomized complete-block design was used with a total of four blocks. Each block had eight plants of 'Nugget Supreme'. Statistical analysis was conducted as in Expt. 1.

Plant culture. 'Nugget Supreme' seeds were sown on 17 Oct. 1993 and transplanted to inserts on 25 Oct., as described for Expt. 1. After seedlings were transplanted to inserts, the flats were placed in a growth room at $22 \pm$ $2 \mathrm{C}$ and $16 \mathrm{~h}$ of irradiance at $190 \pm 30$ $\mu \mathrm{mol} \cdot \mathrm{m}^{-2} \cdot \mathrm{s}^{-1} \mathrm{PAR}$. Seedlings were transplanted to $500-\mathrm{ml}(10-\mathrm{cm})$ round pots 1 week after transplanting to inserts. Plants were grown in a growth room at $22 \pm 2 \mathrm{C}$ and $16 \mathrm{~h}$ of a combination of fluorescent and incandescent light with an irradiance of $210 \pm 30 \mu \mathrm{mol} \cdot \mathrm{m}^{-2} \cdot \mathrm{s}^{-1}$ PAR. Potted plants were grown for 5 weeks and harvested on 9 Dec. 1993.

Data collection. Flowering dates, number of buds, number of branches, plant height, and shoot fresh and dry weights were recorded as described for Expt. 1. The total volume of leachate from each individual pot was collected over the entire experiment and analyzed for $\mathrm{P}$ content. Roots were harvested for length and dry weight determination. The $\mathrm{pH}$ of the growing medium was measured by the saturated medium extract procedure of Warncke (1986).

The medium was washed from roots, and three to five representative root branches or root sections were sampled for length determination. The root sample represented $<1 \%$ of the root system. Roots were stained in $10 \%$ isopropanol with $1 \%$ methyl violet stain $(1 \mathrm{~g}$ methyl violet $2 \mathrm{~B}$ and $100 \mathrm{ml} 95 \%$ ethanol). After 24 to $48 \mathrm{~h}$, roots were destained with fresh $10 \%$ isopropanol. Stained roots were submerged in $3 \mathrm{~mm}$ of water and digitized with a flat-bed scanner (Deskscan II; HewlettPackard, San Jose, Calif.). Root length was estimated from scanned images by RootLaw (Washington State Univ., Pullman). The dry weight of samples used for length determination then was used to calculate specific root length (centimeter root per gram dry weight of root), from which the length of the total root system was estimated.

\section{Results}

\section{Experiment 1}

Shoot growth. 'Sophia', 'Nugget Supreme', and 'Discovery' had similar foliage color regardless of P treatment, but 'Inca' plants treated with $\mathrm{CNS}$ or $\mathrm{P}-\mathrm{Al}_{2} \mathrm{O}_{3}$ were chlorotic. Within a cultivar, plant heights were similar among treatments after 4 or 8 weeks (data not shown). 'Sophia' and 'Nugget Supreme' showed no difference among treatments in flowering date, number of flowers, buds, or flowers plus buds (data not shown). 'Discovery' and 'Inca' plants are late-flowering and usually sold green in commerce. They did not reach reproductive stage by the final harvest. 'Sophia' and 'Discovery' treated with $\mathrm{P}-\mathrm{Al}_{2} \mathrm{O}_{3}$ produced slightly more branches (Fig. 1) and were heavier (fresh weight) (Fig. 2) than the $20 \mathrm{~N}-4.4 \mathrm{P}-16.6 \mathrm{~K}$ or CNS-fertilized plants. 'Nugget Supreme' plants in the $\mathrm{P}-\mathrm{Al}_{2} \mathrm{O}_{3}$ treatments were heavier than plants grown in $20 \mathrm{~N}-4.4 \mathrm{P}-16.6 \mathrm{~K}$ (control) or CNS. 'Inca' plants produced the same number of branches in all treatments, and shoot fresh weights with $8 \% \mathrm{P}-\mathrm{Al}_{2} \mathrm{O}_{3}$ were higher than for the control. Dry weight trends were identical to fresh weight trends (data not shown).

The symptoms of $\mathrm{P}$ deficiency are retarded growth, delayed reproduction, small dark green leaves, and enhanced anthocyanin formation, which causes reddish or purplish coloration on stems and veins (Bergmann, 1992). Marigolds deficient in $\mathrm{P}$ usually develop red discoloration on the margins of old leaves that spreads throughout the plant (Nelson, 1985). We did not observe any of these deficiency symptoms

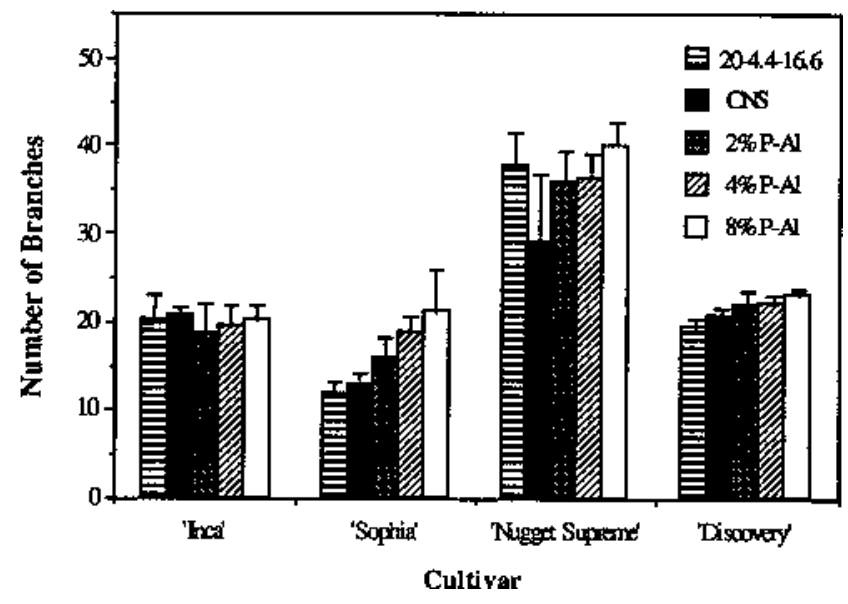

Fig. 1. Number of branches produced by 8 -week-old marigolds. Each bar represents the mean of four plants \pm standard deviation of the mean. $20 \mathrm{~N}-4.4 \mathrm{P}-16.6 \mathrm{~K}$ : plants fertilized with $20 \mathrm{~N}-4.4 \mathrm{P}-16.6 \mathrm{~K}$ fertilizer; CNS: plants fertilized with complete nutrient solution; P-Al: plants grown in media amended with the given percentage of $\mathrm{P}-\mathrm{Al}_{2} \mathrm{O}_{3}$ by media volume. $\mathrm{F}$ test: 'Inca', $\mathrm{F}=0.49^{\text {ss; }}$ 'Sophia', $\mathrm{F}=11.00^{* * * *}$; 'Nugget Supreme', $\mathrm{F}=3.23^{*}$; 'Discovery', $\mathrm{F}=12.3^{*}$. ns, ${ }^{*, * * *}$ Nonsignificant or significant at $P \leq 0.05$ or 0.001 , respectively.

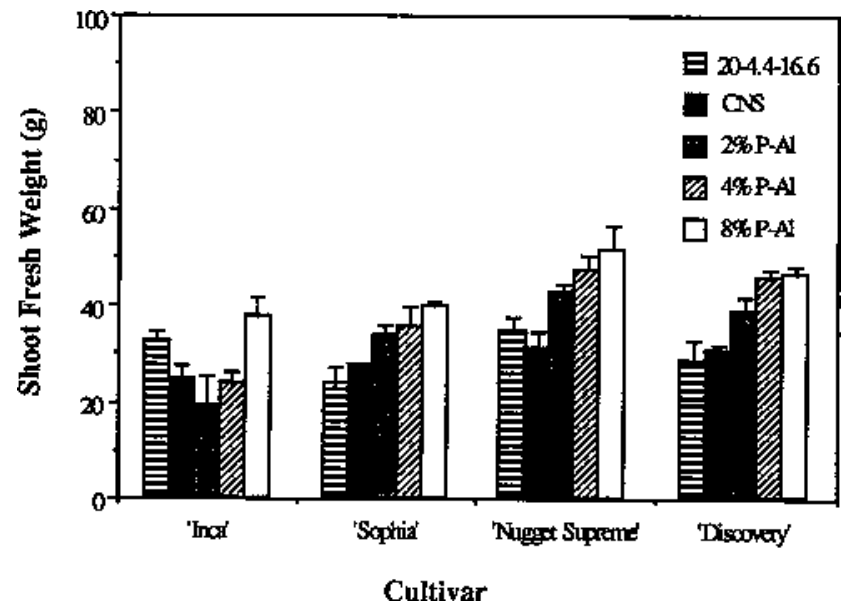

Fig. 2. Shoot fresh weight (in grams) of 8-week-old marigolds. Each bar represents the mean of four plants \pm standard deviation of the mean. $20 \mathrm{~N}-4.4 \mathrm{P}-16.6 \mathrm{~K}$ : plants fertilized with $20 \mathrm{~N}-4.4 \mathrm{P}-16.6 \mathrm{~K}$ fertilizer; CNS: plants fertilized with complete nutrient solution; P-Al: plants grown in media amended with the given percentage of $\mathrm{P}-\mathrm{Al}_{2} \mathrm{O}_{3}$ by media volume. F test: 'Inca', $\mathrm{F}=13.65^{* * * *}$; 'Sophia', $\mathrm{F}=23.38^{* * *}$; 'Nugget Supreme', $\mathrm{F}=22.95^{* * *}$; 'Discovery', $\mathrm{F}=52.74^{* * * *}$. ${ }^{* * *}$ Significant at $P \leq 0.001$. 
on marigolds grown in $\mathrm{P}-\mathrm{Al}_{2} \mathrm{O}_{3}$-amended medium or in medium fertilized with CNS or $20 \mathrm{~N}-4.4 \mathrm{P}-16.6 \mathrm{~K}$.

Another symptom of $\mathrm{P}$ deficiency is an increased root : shoot dry-weight ratio (Anghinoni and Barber, 1980). With three cultivars, the root : shoot ratios of the $\mathrm{P}-\mathrm{Al}_{2} \mathrm{O}_{3}$ and CNS-fertilized plants were not significantly different from each other but were different from the control plants (Table 2). The root : shoot ratio of 'Inca' was lower in the $\mathrm{P}-\mathrm{Al}_{2} \mathrm{O}_{3}$ treatments than when $20 \mathrm{~N}-4.4 \mathrm{P}-$ $16.6 \mathrm{~K}$ was used. The $\mathrm{P}$ concentrations in shoots and roots of control plants were higher than in $\mathrm{P}-\mathrm{Al}_{2} \mathrm{O}_{3}$ or CNS-fertilized plants (Table 3). Conventional fertilizer appears to have supplied more $\mathrm{P}$ than required. Jones et al. (1991) suggested that $\mathrm{P}$ concentrations in begonia (Begonia $\times$ semperflorens-cultorum Hort.) foliage $>0.75 \%$ are high and that concentrations would probably be similar for marigold. Conventionally fertilized plants accumulated more $\mathrm{P}$ but did not manifest superior growth. Plants grown with higher rates of $\mathrm{P}-\mathrm{Al}_{2} \mathrm{O}_{3}(8 \%)$ had slightly higher shoot weights than plants grown with $2 \%$ (Fig. 2), probably because plants grown with the former were provided with more P. Plants provided $8 \% \mathrm{P}-\mathrm{Al}_{2} \mathrm{O}_{3}$, however, had similar $\mathrm{P}$ concentrations as CNSfertilized plants, but the $\mathrm{P}-\mathrm{Al}_{2} \mathrm{O}_{3}$ fertilized plants had higher shoot weights.

The difference between the $20 \mathrm{~N}-4.4 \mathrm{P}$ $16.6 \mathrm{~K}$ and CNS-fertilized plants was likely due to the different components in the two solutions (Table 1). The difference between the $\mathrm{CNS}$ and $\mathrm{P}-\mathrm{Al}_{2} \mathrm{O}_{3}$ treatments, however, was the manner of supplying $\mathrm{P}$. The more $\mathrm{P}-\mathrm{Al}_{2} \mathrm{O}_{3}$ applied in the medium, the greater its P-buffering capacity. Phosphorus was buffered by the $\mathrm{P}-\mathrm{Al}_{2} \mathrm{O}_{3}$ in the medium that provided a slow-released $P$ source, thus creating a constant $\mathrm{P}$ supply for root uptake (Coltman et al., 1982).

Phosphorus concentration ofleachate. The various fertilizer treatments had marked effects on P leaching from the pots (Fig. 3). Phosphorus leaching over the entire duration of the experiment was greatest for $20 \mathrm{~N}-4.4 \mathrm{P}-$ $15.5 \mathrm{~K}$ control. Increased $\mathrm{P}$ leaching after week 4 may have been due to increased irrigation frequency. The CNS leached only about half as much $\mathrm{P}$ as the control. Phosphorus leaching from the $\mathrm{P}-\mathrm{Al}_{2} \mathrm{O}_{3}$ treatments declined over the first 3 weeks to very low levels for the duration of the experiment and was less than for any other treatment. The initial release of $\mathrm{P}$ from the $4 \%$ and $8 \% \mathrm{P}_{-} \mathrm{Al}_{2} \mathrm{O}_{3}$ treatments may represent loosely bound $\mathrm{P}$ that could be removed by rinsing before use (Elliott, 1989).

\section{Experiment 2}

Shoot growth. 'Nugget Supreme' showed no difference in coloration, height, days to flower initiation, number of flowers, or number of flower buds among fertilizer treatments (data not shown). Plants treated with $\mathrm{P}-\mathrm{Al}_{2} \mathrm{O}_{3}$ at $1 \%, 4 \%, 12 \%$, and $16 \%$ produced more branches than plants fertilized with $20 \mathrm{~N}-4.4 \mathrm{P}-$ $16.6 \mathrm{~K}$ (control) (Table 4). Plants grown with $\mathrm{P}-\mathrm{Al}_{2} \mathrm{O}_{3}$ were heavier than the controls or
CNS-fertilized plants, except plants receiving $4 \%$ and $16 \% \mathrm{P}-\mathrm{Al}_{2} \mathrm{O}_{3}$, which had similar dry weights as CNS-fertilized plants. Plants grown with $\mathrm{P}-\mathrm{Al}_{2} \mathrm{O}_{3}$ generally had lower root : shoot dry-weight ratios than CNS-fertilized plants (data not shown).

Root growth. Plants grown with $\mathrm{P}-\mathrm{Al}_{2} \mathrm{O}_{3}$ developed a more compact root system than plants grown in CNS or $20 \mathrm{~N}-4.4 \mathrm{P}-16.6 \mathrm{~K}$. The latter two groups had a loose rootball with long, thin roots, with most of the roots near the bottom of the pot. The medium was easily

Table 2. Root : shoot dry-weight ratio of 8-week-old marigold cultivars fertilized with $20 \mathrm{~N}-4.4 \mathrm{P}-16.6 \mathrm{~K}$, complete nutrient solution (CNS), or $\mathrm{P}-\mathrm{Al}_{2} \mathrm{O}_{3}$.

\begin{tabular}{lllrr}
\hline \hline & \multicolumn{3}{c}{ Cultivar } \\
\cline { 2 - 5 } Fertilizer & Inca $^{2}$ & Sophia & Nugget Supreme & Discovery \\
\hline $20 \mathrm{~N}-4.4 \mathrm{P}-16.6 \mathrm{~K}$ (control) & $0.31 \mathrm{a}$ & $0.34 \mathrm{a}$ & $0.13 \mathrm{a}$ & $0.37 \mathrm{a}$ \\
$\mathrm{CNS}$ & $0.16 \mathrm{~b}$ & $0.21 \mathrm{~b}$ & $0.12 \mathrm{a}$ & $0.24 \mathrm{~b}$ \\
$\mathrm{P}-\mathrm{Al}_{2} \mathrm{O}_{3}, 2 \%$ & $0.09 \mathrm{c}$ & $0.27 \mathrm{~b}$ & $0.10 \mathrm{a}$ & $0.23 \mathrm{~b}$ \\
$\mathrm{P}-\mathrm{Al}_{2} \mathrm{O}_{3}, 4 \%$ & $0.10 \mathrm{c}$ & $0.27 \mathrm{~b}$ & $0.12 \mathrm{a}$ & $0.20 \mathrm{~b}$ \\
$\mathrm{P}-\mathrm{Al}_{2} \mathrm{O}_{3}, 8 \%$ & $0.13 \mathrm{bc}$ & $0.28 \mathrm{ab}$ & $0.12 \mathrm{a}$ & $0.25 \mathrm{~b}$ \\
Analysis of variance & & & 1.41 & $5.37^{* *}$ \\
$\quad \mathrm{~F}$ value & $24.87^{* * *}$ & $4.99^{* * *}$ & & \\
\hline
\end{tabular}

${ }^{2}$ Mean of four plants. Mean separation within columns by Waller-Duncan's k ratio $t$ test at $P \leq 0.05$.

${ }^{* * * * * * *}$ Significant at $P \leq 0.01$ or 0.001 , respectively.

Table 3. Phosphorus concentration (percent dry weight) in shoots and roots of 8-week-old marigold cultivars fertilized with $20 \mathrm{~N}-4.4 \mathrm{P}-16.6 \mathrm{~K}$, complete nutrient solution (CNS), or $\mathrm{P}-\mathrm{Al}_{2} \mathrm{O}_{3}$.

\begin{tabular}{|c|c|c|c|c|}
\hline \multirow[b]{3}{*}{ Fertilizer } & \multicolumn{4}{|c|}{$\mathrm{P}(\%)$} \\
\hline & \multicolumn{4}{|c|}{ Cultivar } \\
\hline & Inca $^{2}$ & Sophia & Nugget Supreme & Discovery \\
\hline \multicolumn{5}{|l|}{ Shoots } \\
\hline $20 \mathrm{~N}-4.4 \mathrm{P}-16.6 \mathrm{~K}$ (control) & $0.78 \mathrm{a}$ & $1.28 \mathrm{a}$ & $0.93 \mathrm{a}$ & $1.04 \mathrm{a}$ \\
\hline CNS & $0.43 \mathrm{~b}$ & $0.59 \mathrm{c}$ & $0.57 \mathrm{~b}$ & $0.51 \mathrm{bc}$ \\
\hline $\mathrm{P}-\mathrm{Al}_{2} \mathrm{O}_{3}, 2 \%$ & $0.30 \mathrm{~b}$ & $0.56 \mathrm{c}$ & $0.40 \mathrm{c}$ & $0.42 \mathrm{c}$ \\
\hline $\mathrm{P}-\mathrm{Al}_{2} \mathrm{O}_{3}, 4 \%$ & $0.29 \mathrm{~b}$ & $0.67 \mathrm{bc}$ & $0.51 \mathrm{bc}$ & $0.47 \mathrm{c}$ \\
\hline $\mathrm{P}-\mathrm{Al}_{2} \mathrm{O}_{3}, 8 \%$ & $0.38 \mathrm{~b}$ & $0.77 \mathrm{~b}$ & $0.60 \mathrm{~b}$ & $0.60 \mathrm{~b}$ \\
\hline \multicolumn{5}{|l|}{ Analysis of variance } \\
\hline F value & $14.62^{* * *}$ & $29.05^{* * * *}$ & $15.01^{* * * *}$ & $37.21^{* * *}$ \\
\hline \multicolumn{5}{|l|}{ Roots } \\
\hline $20 \mathrm{~N}-4.4 \mathrm{P}-16.6 \mathrm{~K}$ (control) & $0.67 \mathrm{a}$ & $0.66 \mathrm{a}$ & $0.57 \mathrm{a}$ & $0.60 \mathrm{a}$ \\
\hline CNS & $0.30 \mathrm{~b}$ & $0.48 \mathrm{~b}$ & $0.31 \mathrm{~b}$ & $0.37 \mathrm{~b}$ \\
\hline $\mathrm{P}-\mathrm{Al}_{2} \mathrm{O}_{3}, 2 \%$ & $0.25 \mathrm{bc}$ & $0.28 \mathrm{c}$ & $0.20 \mathrm{c}$ & $0.20 \mathrm{~d}$ \\
\hline $\mathrm{P}-\mathrm{Al}_{2} \mathrm{O}_{3}, 4 \%$ & $0.26 \mathrm{bc}$ & $0.38 \mathrm{bc}$ & $0.22 \mathrm{c}$ & $0.30 \mathrm{c}$ \\
\hline $\mathrm{P}-\mathrm{Al}_{2} \mathrm{O}_{3}, 8 \%$ & $0.20 \mathrm{c}$ & $0.34 \mathrm{c}$ & $0.24 \mathrm{c}$ & $0.36 \mathrm{~b}$ \\
\hline \multicolumn{5}{|l|}{ Analysis of variance } \\
\hline F value & $34.60^{* * *}$ & $18.16^{* * * *}$ & $52.78^{* * * *}$ & $53.94^{* * * *}$ \\
\hline
\end{tabular}

${ }^{2}$ Mean of four plants. Mean separation within columns by Waller-Duncan's k ratio $t$ test at $P \leq 0.05$.

${ }^{* * *}$ Significant at $P \leq 0.001$.

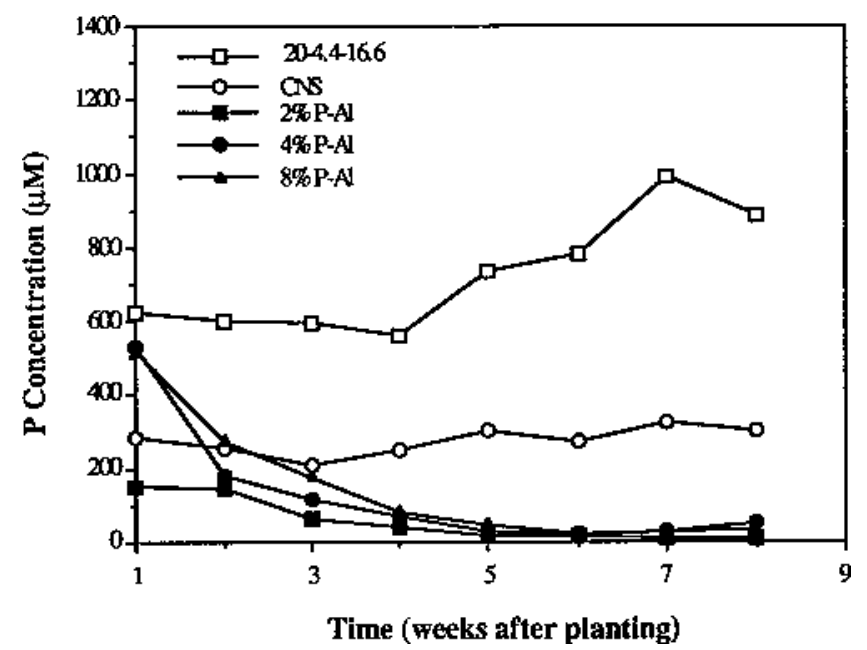

Fig. 3. Leachate P concentration (in micromoles) of 'Nugget Supreme' marigold over 8 weeks of growth. Each point represents a combined sample from four plants. 
applied, ranging from the highest values of all fertilizer treatments, through values similar to those for $20 \mathrm{~N}-4.4 \mathrm{P}-16.6 \mathrm{~K}$, to values as low as for CNS plants (Table 5). The distribution of $\mathrm{P}$ in plants and leachate was determined as a proportion of the total amount of $\mathrm{P}$ applied to the medium throughout the growing season. In plants fertilized with $20 \mathrm{~N}-4.4 \mathrm{P}-16.6 \mathrm{~K}$ and $\mathrm{CNS},>70 \%$ of the $\mathrm{P}$ applied was leached and $<30 \%$ was taken up by the plants (Table 6). In contrast, $<4 \%$ of applied $\mathrm{P}$ was leached from the $\mathrm{P}-\mathrm{Al}_{2} \mathrm{O}_{3}$ treatments. Compared to the CNS treatment, $\mathrm{P}-\mathrm{Al}_{2} \mathrm{O}_{3}$ amendments $<4 \%$ reduced the total amount of $\mathrm{P}$ leaching. As in the first experiment, $70 \%$ to $80 \%$ of the $\mathrm{P}$ leached appeared in the first third of the leachate from alumina-amended pots (Table 5 and Fig. 3). When $\mathrm{P}-\mathrm{Al}_{2} \mathrm{O}_{3}$ amendments exceeded $8 \%$, heavy $\mathrm{P}$ leaching occurred during the first two-thirds (5 weeks) of the crop.

\section{Discussion}

Phosphorus-loaded alumina was evaluated as a buffered $\mathrm{P}$ source for marigold cultivation in peatlite medium. Phosphorus-charged alumina amendments as low as $1 \%$ on a volume basis were sufficient to provide adequate $\mathrm{P}$ nutrition. Plants fertilized with $\mathrm{P}-\mathrm{Al}_{2} \mathrm{O}_{3}$ had lower tissue $\mathrm{P}$ levels than plants fertilized with CNS or $20 \mathrm{~N}-4.4 \mathrm{P}-16.6 \mathrm{~K}$ (control) fertilizer but had similar or superior shoot growth. Phos-

Table 4. Shoot growth as measured by height, number of branches, shoot fresh weight (SFW), and shoot dry weight (SDW) of 5-week-old 'Nugget Supreme' marigold fertilized with 20N-4.4P-16.6K, complete nutrient solution (CNS), or $\mathrm{P}-\mathrm{Al}_{2} \mathrm{O}_{3}$.

\begin{tabular}{|c|c|c|c|c|}
\hline Fertilizer & $\mathrm{Ht}(\mathrm{cm})$ & Branches (no.) & SFW (g) & SDW $(g)$ \\
\hline $20 \mathrm{~N}-4.4 \mathrm{P}-16.6 \mathrm{~K}$ (control) & $9.9 \mathrm{a}^{\mathrm{z}}$ & $13 \mathrm{~b}$ & $21.1 \mathrm{c}$ & $2.4 \mathrm{c}$ \\
\hline $\mathrm{CNS}$ & $9.1 \mathrm{a}$ & $15 \mathrm{ab}$ & $23.2 \mathrm{c}$ & $2.6 \mathrm{bc}$ \\
\hline $\mathrm{P}-\mathrm{Al}_{2} \mathrm{O}_{3}, 1 \%$ & $10.4 \mathrm{a}$ & $17 \mathrm{a}$ & $29.4 \mathrm{~b}$ & $3.2 \mathrm{a}$ \\
\hline $\mathrm{P}-\mathrm{Al}_{2} \mathrm{O}_{3}, 2 \%$ & $9.8 \mathrm{a}$ & $14 \mathrm{~b}$ & $29.7 \mathrm{~b}$ & $3.1 \mathrm{a}$ \\
\hline $\mathrm{P}-\mathrm{Al}_{2} \mathrm{O}_{3}, 4 \%$ & $9.6 \mathrm{a}$ & $17 \mathrm{a}$ & $28.9 \mathrm{~b}$ & $3.0 \mathrm{ab}$ \\
\hline $\mathrm{P}-\mathrm{Al}_{2} \mathrm{O}_{3}, 8 \%$ & $9.0 \mathrm{a}$ & $16 \mathrm{ab}$ & $30.7 \mathrm{ab}$ & $3.2 \mathrm{a}$ \\
\hline $\mathrm{P}-\mathrm{Al}_{2} \mathrm{O}_{3}, 12 \%$ & 9.9 a & $17 \mathrm{a}$ & $33.0 \mathrm{a}$ & $3.3 \mathrm{a}$ \\
\hline $\mathrm{P}-\mathrm{Al}_{2} \mathrm{O}_{3}, 16 \%$ & $10.7 \mathrm{a}$ & $17 \mathrm{a}$ & $28.9 \mathrm{~b}$ & $2.9 \mathrm{ab}$ \\
\hline \multicolumn{5}{|l|}{ Analysis of variance } \\
\hline F value & 0.28 & $3.8^{* * *}$ & $12.43^{* * *}$ & $4.82^{* *}$ \\
\hline
\end{tabular}

Table 5. Distribution of applied $\mathrm{P}$ in plant (shoot and root) and three collections of leachate from marigolds fertilized with $20 \mathrm{~N}-4.4 \mathrm{P}-16.6 \mathrm{~K}$, complete nutrient solution (CNS), or $\mathrm{P}-\mathrm{Al}_{2} \mathrm{O}_{3}$.

\begin{tabular}{|c|c|c|c|c|c|}
\hline \multirow[b]{3}{*}{ Fertilizer } & \multicolumn{5}{|c|}{ Distribution (mg) } \\
\hline & \multicolumn{2}{|c|}{ Plant } & \multicolumn{3}{|c|}{ Leachate } \\
\hline & Shoot & Root & $1 \mathrm{st}$ & 2nd & 3rd \\
\hline $20 \mathrm{~N}-4.4 \mathrm{P}-16.6 \mathrm{~K}$ (control) & $28 b^{2}$ & $3.1 \mathrm{a}$ & $26 \mathrm{de}$ & $39 \mathrm{~b}$ & $37.3 \mathrm{a}$ \\
\hline CNS & $21 \mathrm{c}$ & $2.2 \mathrm{~d}$ & $17 \mathrm{df}$ & $24 \mathrm{~d}$ & $15.0 \mathrm{c}$ \\
\hline $\mathrm{P}-\mathrm{Al}_{2} \mathrm{O}_{3}, 1 \%$ & $22 \mathrm{c}$ & $1.2 \mathrm{~d}$ & $13 \mathrm{f}$ & 4 ef & $1.5 \mathrm{~g}$ \\
\hline $\mathrm{P}-\mathrm{Al}_{2} \mathrm{O}_{3}, 2 \%$ & $26 \mathrm{~b}$ & $1.8 \mathrm{c}$ & $25 \mathrm{de}$ & $2 \mathrm{f}$ & $2.1 \mathrm{fg}$ \\
\hline $\mathrm{P}-\mathrm{Al}_{2} \mathrm{O}_{3}, 4 \%$ & $26 \mathrm{~b}$ & $1.8 \mathrm{c}$ & $46 \mathrm{c}$ & $5 \mathrm{e}$ & $3.5 \mathrm{f}$ \\
\hline $\mathrm{P}-\mathrm{Al}_{2} \mathrm{O}_{3}, 8 \%$ & $29 \mathrm{~b}$ & $2.2 \mathrm{~b}$ & $35 \mathrm{~cd}$ & $32 \mathrm{c}$ & $7.5 \mathrm{e}$ \\
\hline $\mathrm{P}-\mathrm{Al}_{2} \mathrm{O}_{3}, 12 \%$ & $36 \mathrm{a}$ & $2.5 \mathrm{a}$ & $58 \mathrm{~b}$ & $24 \mathrm{~d}$ & $11.4 \mathrm{~d}$ \\
\hline $\mathrm{P}-\mathrm{Al}_{2} \mathrm{O}_{3}, 16 \%$ & $37 \mathrm{a}$ & $2.0 \mathrm{a}$ & $75 \mathrm{a}$ & $43 \mathrm{a}$ & $18.6 \mathrm{~b}$ \\
\hline \multicolumn{6}{|l|}{ Analysis of variance } \\
\hline $\mathrm{F}$ value & $34.55^{* * * *}$ & $14.16^{* * * *}$ & $28.31^{* * * *}$ & $189.18^{* * * *}$ & $486.82^{* * *}$ \\
\hline
\end{tabular}

${ }^{\mathrm{z}}$ Mean of four plants. Mean separation within columns by Waller-Duncan's k ratio $t$ test at $P \leq 0.05$.

${ }^{* * * *}$ Significant at $P \leq 0.001$.

Table 6. Phosphorus distribution in plant, leachate, and medium. The amount (in milligrams) of $\mathrm{P}$ was measured from plant tissue and leachate. The total $\mathrm{P}$ applied from $20 \mathrm{~N}-4.4 \mathrm{P}-16.6 \mathrm{~K}$ and solution was calculated from their $\mathrm{P}$ content; $\mathrm{P}$ applied from $\mathrm{P}-\mathrm{Al}_{2} \mathrm{O}_{3}$ was calculated by sorption curves for $\mathrm{P}-\mathrm{Al}_{2} \mathrm{O}_{3}$ (Lynch et al., 1990), which adsorbed $\approx 3000 \mu \mathrm{mol} \mathrm{P} / 1 \mathrm{~g} \mathrm{Al}_{2} \mathrm{O}_{3}$ when alumina was saturated with $\mathrm{P}$. The amount of $\mathrm{P}$ left in the media was estimated by subtracting measured $\mathrm{P}$ from total $\mathrm{P}$.

\begin{tabular}{|c|c|c|c|c|}
\hline \multirow[b]{2}{*}{ Treatment } & \multicolumn{4}{|c|}{$\mathrm{P}$ distribution } \\
\hline & $\begin{array}{c}\text { Total P } \\
\text { (mg) }\end{array}$ & $\begin{array}{c}\text { Plant } \\
{[\mathrm{mg}(\%)]}\end{array}$ & $\begin{array}{l}\text { Leachate } \\
{[\mathrm{mg}(\%)]}\end{array}$ & $\begin{array}{c}\text { Media } \\
{[\mathrm{mg}(\%)]}\end{array}$ \\
\hline $20 \mathrm{~N}-4.4 \mathrm{P}-16.6 \mathrm{~K}$ (control) & $138^{\mathrm{z}}$ & 32 b (22.9) & $102 \mathrm{~b}(74.0)$ & $4 \mathrm{~g} \mathrm{(3.1)}$ \\
\hline CNS & 77 & $23 \mathrm{~d}(29.6)$ & $56 \mathrm{~d}(72.4)$ & $(-) 2 \mathrm{~g}(0.0)$ \\
\hline $\mathrm{P}-\mathrm{Al}_{2} \mathrm{O}_{3}, 1 \%$ & 570 & $23 \mathrm{~d}(4.0)$ & $19 \mathrm{e}(3.3)$ & $528 \mathrm{f}(92.6)$ \\
\hline $\mathrm{P}-\mathrm{Al}_{2} \mathrm{O}_{3}, 2 \%$ & 1018 & $28 \mathrm{c}(2.8)$ & 30 e (2.9) & 960 e (94.3) \\
\hline $\mathrm{P}-\mathrm{Al}_{2} \mathrm{O}_{3}, 4 \%$ & 2195 & $28 \mathrm{c}(1.3)$ & $55 \mathrm{~d}(2.5)$ & $2112 \mathrm{~d}(96.2)$ \\
\hline $\mathrm{P}-\mathrm{Al}_{2} \mathrm{O}_{3}, 8 \%$ & 4330 & $31 \mathrm{~b}(0.7)$ & $75 \mathrm{c}(1.7)$ & $4224 \mathrm{c}(97.6)$ \\
\hline $\mathrm{P}-\mathrm{Al}_{2} \mathrm{O}_{3}, 12 \%$ & 6467 & 38 a $(0.6)$ & $93 \mathrm{~b}(1.4)$ & $6336 \mathrm{~b}(98.0)$ \\
\hline $\mathrm{P}-\mathrm{Al}_{2} \mathrm{O}_{3}, 16 \%$ & 8624 & 39 a $(0.4)$ & 137 a (1.6) & 8448 a $(98.0)$ \\
\hline \multicolumn{5}{|l|}{ Analysis of variance $(\mathrm{mg} \mathrm{P})$} \\
\hline F value & & $34.55^{* * * *}$ & $82.58^{* * *}$ & $9999.9^{* * *}$ \\
\hline
\end{tabular}

phorus leaching from $\mathrm{P}-\mathrm{Al}_{2} \mathrm{O}_{3}$-fertilized pots was substantially less than from CNS and or from the controls as a proportion of applied $\mathrm{P}$ and, in absolute terms, was lowest in pots amended with low rates of $\mathrm{P}-\mathrm{Al}_{2} \mathrm{O}_{3}$. Phosphorus leaching from $\mathrm{P}-\mathrm{Al}_{2} \mathrm{O}_{3}$-amended pots probably could be reduced further by rinsing the $\mathrm{P}-\mathrm{Al}_{2} \mathrm{O}_{3}$ before incorporation in the medium.

We had anticipated that $\mathrm{Al}$ toxicity might limit the use of $\mathrm{P}-\mathrm{Al}_{2} \mathrm{O}_{3}$ at the higher treatment rates. Our observation that roots appeared stunted at $12 \%$ and $16 \% \mathrm{P}-\mathrm{Al}_{2} \mathrm{O}_{3}$ may indicate that $\mathrm{Al}$ toxicity did occur at those rates, although overall root length and plant growth were not affected. This problem could be avoided by maintenance of medium $\mathrm{pH}$ to $>5.2$, where the solid alumina would not be soluble, although rhizosphere acidification may still cause local Al solubilization, especially in fertilizer regimes containing high ratios of ammonium to nitrate. In any case, potential $\mathrm{Al}$ toxicity does not appear to represent a problem to the potential use of solid alumina as a $\mathrm{P}$ fertilizer since the alumina was effective at very low rates of application, in which root stunting was absent.

Efforts to alleviate $\mathrm{P}$ leaching in soilless media are necessary because greenhouse growers soon may face state regulation of the chemical content of runoff. Reducing P leaching also would result in more efficient fertilizer use. Our study had promising results, showing that quality marigolds could be produced and $\mathrm{P}$ leaching from soilless medium could be reduced by adding a small amount of $\mathrm{P}-\mathrm{Al}_{2} \mathrm{O}_{3}$ into the soilless mixture. Future studies on amending $\mathrm{P}-\mathrm{Al}_{2} \mathrm{O}_{3}$ in soilless media will need to evaluate more types of potted plants, especially nursery crops, which usually need a longer period of cultivation before marketing. Root response to the charged alumina also is important, particularly with species sensitive to Al. The postharvest impact of producing plants with $\mathrm{P}-\mathrm{Al}_{2} \mathrm{O}_{3}$ also will be worth investigating.

\section{Literature Cited}

Anghinoni, I. and S.A. Barber. 1980. Phosphorus influx and growth characteristics of corn roots as influenced by phosphorus supply. Agron. J. 72:685-688.

Bergmann, W. (ed.). 1992. Nutritional disorders of plants: Visual and analytical diagnosis. Gustav Fisher Verlag, New York.

Bunt, A.C. 1988. Media and mixes for containergrown plants: A manual on the preparation and use of growing media for pot plants. 2nd ed. Unwin Hyman, London.

Coltman, R.R., G.C. Gerloff, and W.H. Gabelman 1982. A sand culture system for simulating plant responses to phosphorus in soil. J. Amer. Soc. Hort. Sci. 107:938-942.

Elliott, G.C. 1989. Evaluation of sand-alumina-P media for studies of P nutrition. J. Plant Nutr. 12:265-278.

Elliott, G.C., R.M. Carlson, A. Lauchli, and C.J. Rosen, 1983. A solid-phase buffer technique to maintain low concentrations of phosphate in nutrient solutions. J. Plant Nutr. 6:1043-1058.

Flegmann, A.W. and R.A.T. George. 1977. Soils and other growth media. AVI, Westport, Conn.

Fox, R.L. and E.J. Kamprath. 1971. Adsorption and leaching of $\mathrm{P}$ in acid organic soils and high 
organic sand. Proc. Soil Sci. Soc. Amer. 35:154156.

Jones, J.B., Jr., B. Wolf, and H.A. Mills. 1991. Plant analysis handbook: A practical sampling, preparation, analysis, and interpretation guide. 1st ed. Micro-Macro, Athens, Ga.

Lynch, J., E. Epstein, A. Lauchli, and G.I. Weigt. 1990. An automated greenhouse sand culture system suitable for studies of P nutrition. Plant, Cell Environ. 13:547-554.

Marconi, D.J. and P.V. Nelson. 1984. Leaching of applied phosphorus in container media. Sci. Hort. 22:275-285.

Murphy, J. and J.P. Riley. 1962. A modified single solution reagent for the determination of phosphate in natural waters. Analytica Chimica Acta 27:31-36.

Nelson, P.V. 1985. Fertilization, p. 151-175. In J.W. Mastalerz and E.J. Holcomb (eds.). Bedding plants III. A manual on the culture of bedding plants as greenhouse crop. Pennsylvania Flower Growers, Fogelsville.

Nelson, P.V. 1991. Greenhouse operation and management. 4th ed. Prentice-Hall, Englewood Cliffs, N.J.

SAS Institute. 1989. SAS/STAT user's guide, 4th ed. Version 6, vol. 1, 2. SAS Inst., Cary, N.C.

Warncke, D.D. 1986. Analyzing greenhouse growth media by the saturation extraction method. HortScience 21:223-225.

Yeager, T.H. and J.E. Barrett. 1984. Phosphorus leaching from ${ }^{32} \mathrm{P}$-superphosphate-amended soilless container media. HortScience 19:216217.

Yeager, T.H. and J.E. Barrett. 1985. Phosphorus and sulfur leaching from an incubated superphosphate-amended soilless container medium. HortScience 20:671-672.

Yeager, T.H. and J.E. Barrett. 1986. Influence of an anion exchange resin on phosphorus and sulfur leaching from a soilless container medium. HortScience 21:152. 